\title{
TRANSMEMBRANE ION AND WATER TRANSPORTS IN ERYTHROCYTE VOLUME HOMEOSTASIS: AN OVERVIEW OF THE PHYSIOLOGIC PROCESSES
}

Igbokwe NA

Department of Veterinary Physiology and Biochemistry, Faculty of Veterinary Medicine University of Maiduguri, Maiduguri, Borno State, Nigeria

Correspondences and reprint request to: DR NANANCHA AFIFI IGBOKWE, Department of Veterinary Physiology and Biochemistry, Faculty of Veterinary Medicine, University of Maiduguri, P M B 1069, Maiduguri, Borno State, Nigeria

Email: naigbokwe@gmail.com Phone: +2348060175771

\begin{abstract}
Background: The intraerythrocytic concentrations of ions $\left(\mathrm{Na}^{+}, \mathrm{K}^{+}, \mathrm{Cl}^{-}\right.$and $\left.\mathrm{HCO}_{3}^{-}\right)$play key roles in maintaining erythrocyte volume homeostasis. Anisosmotic and isosomotic changes of these ion concentrations challenge erythrocyte volume to either shrink or swell, thereby sending signals to activate regulatory volume mechanisms that are mediated by ion transporters. Ion fluxes directed inwardly or outwardly with obliged water movements do restore the erythrocyte volume to its steady state. These physiological phenomena prevent the erythrocyte from becoming overhydrated or dehydrated with the consequence of intravascular haemolysis or senescent changes associated with eryptosis. Objectives: To review the literature on the physiological processes associated with transmembrane ion and water transports during erythrocyte volume homeostasis. Method: Offline and online libraries were searched with indexing tools using keywords derived from the subject area of review. Conclusions: The review has highlighted the physiological concepts involved in erythrocyte volume homeostasis in relation to the engaged transmembrane ion and water transport systems, which can influence experimental designs to study ion and water channel blockers and channelopathies of erythrocytes.
\end{abstract}

Keywords: Erythrocyte channelopathy, Erythrocyte volume, Homeostasis, Regulatory volume mechanism, Transmembrane transport, Water and ion channels

\section{INTRODUCTION}

Erythrocytes are produced through erythropoiesis whereby the erythrocyte volume is determined after the nucleus and organelles are eliminated. ${ }^{1,2}$ The erythrocyte volume estimated as the mean corpuscular volume ${ }^{3}$ is homeostatically guarded by the equilibrium of osmolarity in the intracellular and extracellular compartments. ${ }^{4}$ Changes in transmembrane osmolarity which create osmotic gradient across the membrane automatically causes

\section{Access this article online}

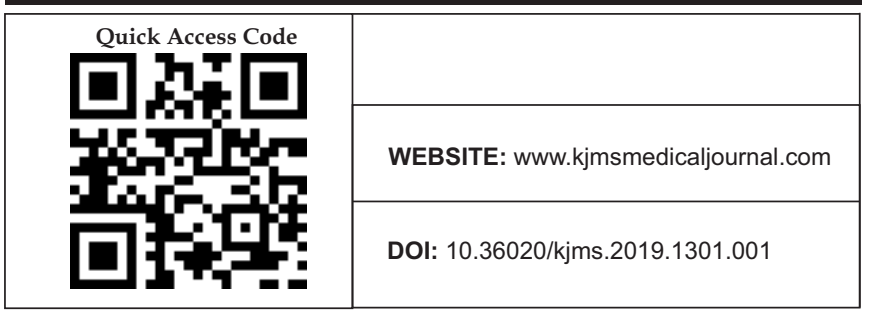

osmotic water flow across the membrane ${ }^{5}$ leading to changes in cell volume. ${ }^{6}$ Continuous swelling of erythrocytes leads to haemolysis ${ }^{7,8}$ while dehydration causes an osmotic shock associated with eryptosis ${ }^{9,10}$ and macrophagic removal of such cells in reticuloendothelial system. ${ }^{11-13}$ The volume changes are resisted by physiological processes that produce changes in cytosolic ionic concentration in order to maintain a steady state in erythrocyte volume. ${ }^{14}$ This present review was aimed at identifying the important physiological processes involved in erythrocyte volume homeostasis in relation to transmembrane ion and water transports. The physiological phenomena were explored through extensive literature 
search in the internet and offline sources, with relevant key words, in order to articulate an overview of current concepts dealing with circumstances associated with erythrocyte volume alterations in clinical science. The definitions of some of the physiological principles used in this review are presented in Table 1.

Table 1: The regulation of cell turgor in response to changes in the osmolarity of the external environment.

\begin{tabular}{|c|c|}
\hline Principle & Definition \\
\hline Active Transport & $\begin{array}{l}\text { Transport of ion against concentration } \\
\text { gradient requiring expenditure of } \\
\text { energy }\end{array}$ \\
\hline Donnan Principle & $\begin{array}{l}\text { There is electrochemical balance across } \\
\text { the membrane irrespective of } \\
\text { intracellular and extracellular ion } \\
\text { concentrations }\end{array}$ \\
\hline Fick's Law & $\begin{array}{l}\text { Flux of ion is directly proportional to } \\
\text { the concentration gradient }\end{array}$ \\
\hline Passive Transport & $\begin{array}{l}\text { Facilitated diffusion moving ion from } \\
\text { fluid of high to low concentration }\end{array}$ \\
\hline Osmosensing & $\begin{array}{l}\text { Recognizing changes in environmental } \\
\text { salinity }\end{array}$ \\
\hline Regulatory Volume Adjustment & $\begin{array}{l}\text { Change in cell size to normalize/rectify } \\
\text { transient osmotic swelling or shrinking }\end{array}$ \\
\hline
\end{tabular}

\section{Membrane structural composition and transmembrane transport pathways}

The cell membrane of erythrocytes is made up of a lipid bilayer which does not allow free movement of molecules and ions across it. The lipids in the membrane are mostly phospholipids. These amphiphilic (or amphipathic) phospholipids consist of a hydrophilic, or polar, phosphate-containing head group attached to two hydrophobic, or nonpolar, fatty acid chains. The phospholipids assemble into a sheet or leaflet. The polar head groups pack together to form the hydrophilic surface of the leaflet, and the nonpolar fatty acid chains form the hydrophobic surface of the leaflet. Two leaflets combine at their hydrophobic surfaces to form a lipid bilayer. ${ }^{15}$ The lipid compositions of the leaflets constituting a single lipid bilayer can differ. Whereas phosphatidyl choline is most abundant in the outer leaflet, phosphatidyl serine is found almost exclusively in the inner leaflet. ${ }^{16}$
Large integral or transmembrane macromolecular proteins consisting of many peptide subunits, either singly or in groups, form water-filled pores that extend across the lipid bilayer of the membrane. They create transport pathways for molecules and ions across the lipid membrane (Figure 1). These proteins involved in transmembrane transport are either carriers or channels having physiological peculiarities. They conduct passive or active ion transport.

The passive transport is a facilitated diffusion which occurs when ions move from a fluid compartment of high ion concentration to another having a lower ion concentration without expenditure of energy. The inward (influx) and outward movements (efflux) of ions across the membrane depends on the concentration gradient of the ions which can be predicted under Fick's law of diffusion which states that the flux of an ion across a membrane is directly proportional to the 


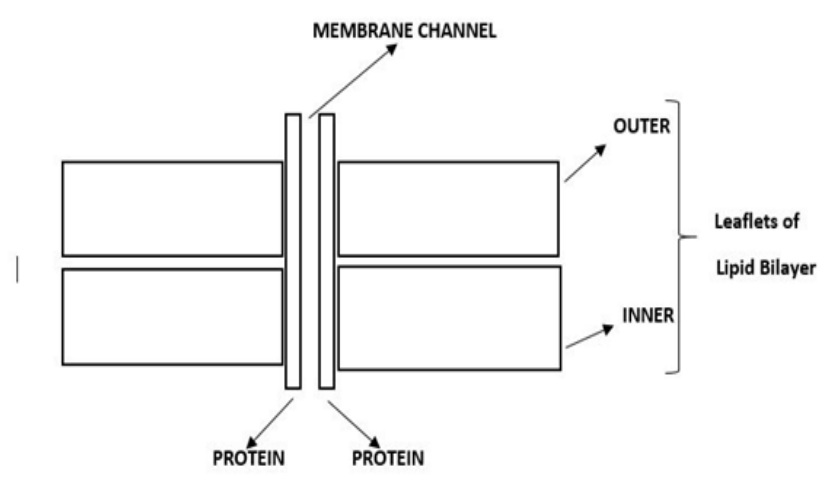

concentration gradient. ${ }^{17}$ The facilitated diffusion may occur through ion transport systems that are either gated or ungated as means of regulation of the transport. The gating may be achieved by internal or external ligands, mechanosenitive proteins or voltage changes in membrane potential (Figure 2).

Figure 1: Protein channel across erythrocyte membrane

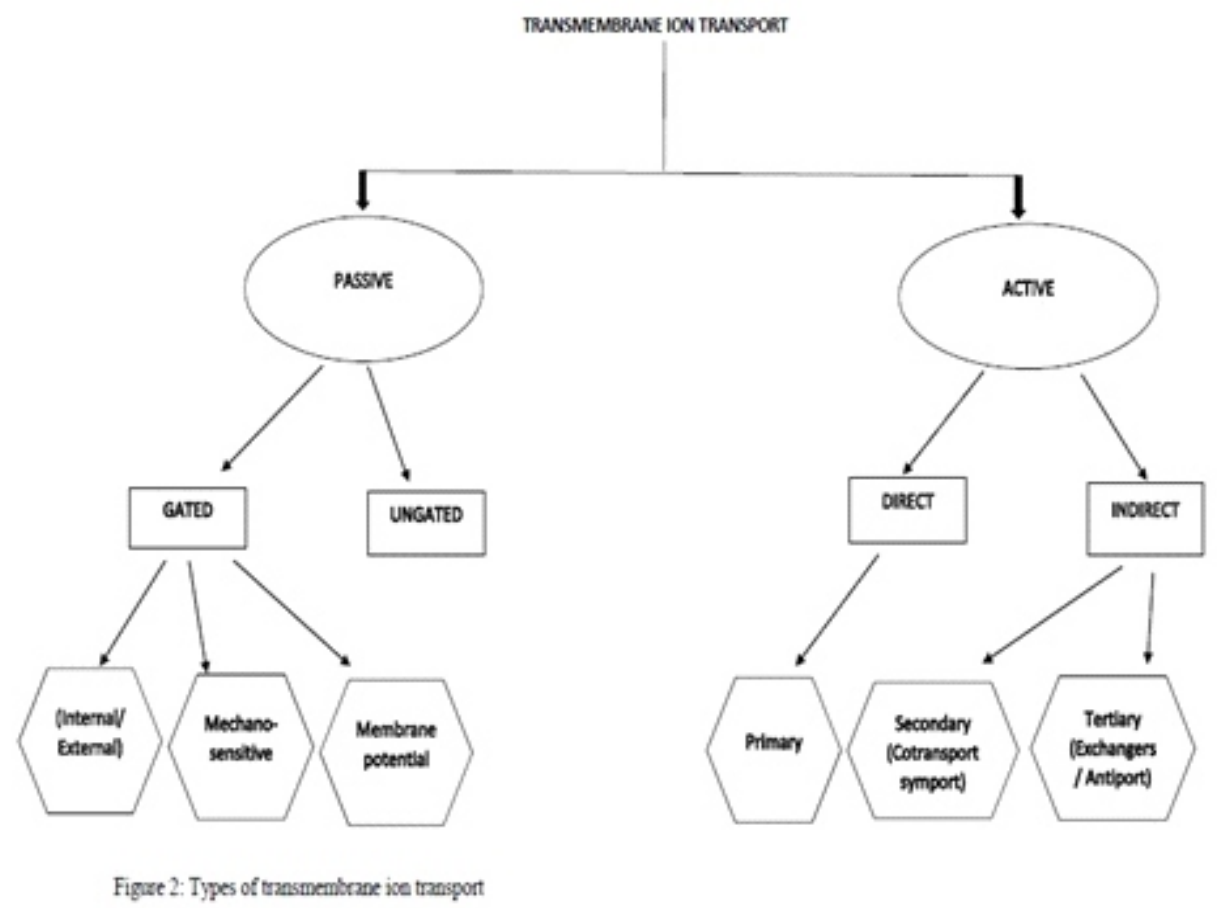

Active transport of ions across a membrane requires expending energy to drive the ion. There are primary, secondary and tertiary active transports as well as direct and indirect active transports. A direct (primary) active transport occurs against the concentration gradient of ions where a driven ion is moved from a fluid compartment of lower concentration to another of higher concentration using energy from the dephosphorylation of adenosine triposphate (ATP). Indirect active transport of ions takes place by transmembrane proteins using energy stored in the gradient of a directly-pumped ion. The concentration gradient of an ion is established by direct active transport and the energy released is used to transport another ion. Two types of indirect active transports are co-transports (secondary active transport) and exchangers (tertiary active transport). In co-transport (symport), the driving ion and another pumped ion or molecule passes through the transmembrane protein in the same direction. In exchanger (antiport) system, the driving ion diffuses through the pump in one direction providing the energy for the active transport of another ion or molecule in the opposite direction (Figure 2). 


\section{Principle of cellular osmoregulatory balance}

Changes in concentration of solutes either in intracellular or extracellular fluid due to anisosmotic or isosmotic factors would cause an osmotic flow of water to the side of the membrane with a greater osmotic pressure. ${ }^{18}$ Swelling of the erythrocyte occurs if the diffusion of water is inward while shrinkage results from an outward diffusion of water. ${ }^{6}$ Ionic fluxes associated with these water movements are guided by Donnan principle to ensure that there is an electrochemical balance despite the irregularities in ion concentrations across the membrane ${ }^{18}$ and cell volume is maintained at a steady state.

\section{Osmosensing by erythrocytes}

Rapid changes of cell volume are usually caused by movement of water across the cell membrane, which is driven by hydrostatic and osmotic pressure gradients across the cell membrane. Erythrocyte swelling and shrinkage exert profound effects on intracellular signalling mechanisms, which in turn modify a multitude of cellular functions including the volume regulatory mechanisms. Erythrocytes exposed to hypotonic or hypertonic extracellular fluid, initially swell or shrink, after which they tend to adjust to the original cell volume by regulatory cell volume decrease (RVD) or regulatory cell volume increase (RVI), respectively. ${ }^{6}$

Erythrocytes are able to detect volume changes by signals picked by sensors that transmit to and activate various ion regulatory transporters. ${ }^{19}$ The signals could be as a result of dilution or macromolecular crowding of the intracellular mileu, ${ }^{14,20}$ changes in ionic strength or concentrations of specific ions, and mechanical or chemical changes in the lipid bilayer. ${ }^{21}$

Alteration of steady state volume causes the activation of Band 3 protein, an anion exchanger $\left(\mathrm{AE}_{1}\right)$ which activates volume regulatory ion channels. ${ }^{22,}{ }^{23}$ Stretching of the membrane also activates a mechanosensitive non-selective cation channel, Piezo $1^{24}$ that is involved in erythrocyte volume homeostasis. ${ }^{25}$ Piezo 1 is a stretch activated cation channel that opens and ultimately counteracts the increase in water influx to avoid erythrocyte lysis during swelling by allowing the influx of calcium ${ }^{26}$ which would influence $\mathrm{Ca}^{2+}$-activated- $\mathrm{K}^{+}$channels (Gardos channels) to open for efflux of $\mathrm{K}^{+27-32}$

The electrochemical concentration and osmotic gradient across the membrane activates swelling-sensitive osmolyte channels $^{33}$ and volume sensitive outwardly rectifying anion channels (VSOACs) ${ }^{34,35,36}$ that determine its permeability to and efflux of $\mathrm{K}^{+}$ and $\mathrm{Cl}^{-37}$ Kinases act as sensors for transmitting signals of cell volume change. ${ }^{38}$ Kinases are inactivated by protein dilution during cell swelling to facilitate influx of $\mathrm{K}^{+}$ and $\mathrm{Cl}^{-}$and activated by protein crowding during cell shrinkage ${ }^{14}$ to inhibit $\mathrm{K}^{+} \mathrm{Cl}^{-}$efflux. The presence of kinases ensures that effective RVI occurs while the presence of kinase inhibitors reduces RVI. ${ }^{39-41}$ Kinases also mediate phosphorylation of proteins which is important for ion transport. ${ }^{37,42,43}$

Protein phosphatase has been reported to activate and also regulate $\mathrm{KCl}$ cotransport. ${ }^{44}$ Inhibition of protein phosphatase abolished swelling activated $\mathrm{K}^{+}$transport in human erythrocytes. ${ }^{44}$ The concentration of oxygen in red cells has been reported to affect $\mathrm{KCl}$ cotransport. ${ }^{37,45}$ At low oxygen levels, cells had a deactivated $\mathrm{KCl}$ co- transporter that was observed by cell swelling due to accumulation of $\mathrm{K}^{+}$via the $\mathrm{Na}^{+} / \mathrm{K}^{+}, \mathrm{Cl}^{-}$cotransporter and osmotically obliged water. ${ }^{37}$ An increase in temperature of the erythrocyte can activate $\mathrm{KCl}$ cotransport. ${ }^{46,47}$ Changes in intracellular $\mathrm{pH}$ can also alter ion fluxes and affect $\mathrm{KCl}$ cotransport. $^{37,48}$

Intraerythrocytic ion composition controlled by transmembrane ion transport

$\mathrm{Na}^{+}, \mathrm{K}^{+}, \mathrm{Cl}^{-}$and $\mathrm{HCO}_{3}{ }^{-}$are intra-erythrocytic ions that are osmotically relevant and their concentrations maintain volume homeostasis. Interspecies and intraspecies differences occur in cation transport and in intracellular concentrations of $\mathrm{Na}^{+}$and $\mathrm{K}^{+} .{ }^{49,50}$ Erythrocytes possess a $\mathrm{Cl}^{-}$-dependent, $\mathrm{Na}^{+}$-independent $\mathrm{K}^{+}$ 
transport system cotransporting $\mathrm{K}^{+}$and $\mathrm{Cl}^{-}$in a 1:1 stoichiometry that is independent of membrane potential. ${ }^{51} \mathrm{~K}^{+}-\mathrm{Cl}^{-}$cotransporters $(\mathrm{KCCs}){ }^{19} \mathrm{Na}^{+}-\mathrm{K}^{+}$$\mathrm{Cl}^{-}$cotransporter ${ }^{52}$ and $\mathrm{Ca}^{2+}$ activated $\mathrm{K}^{+}$channel ${ }^{53}$ are present in erythrocytes for transporting $\mathrm{K}^{+}$. The coupled movements of $\mathrm{Na}^{+}$and $\mathrm{K}^{+}$across erythrocyte membranes are accomplished by a membrane-bound enzyme which demonstrates ATPase activity when incubated with $\mathrm{Na}^{+}$and $\mathrm{K}^{+}$ transporting $3 \mathrm{Na}^{+}$and $2 \mathrm{~K}^{+}$for each ATP split. ${ }^{54.56}$ Maintenance of a low intracellular calcium concentration is necessary for preserving the integrity of erythrocytes. This is achieved by low membrane permeability to calcium in the inward direction and by an active efflux mechanism by the membrane bound enzyme $\mathrm{Ca}^{2+}-\mathrm{Mg}^{2+}$-ATPase. ${ }^{57}$ Erythrocytes actively extrude $\mathrm{Ca}^{2+}$ using a calcium pump having $\mathrm{Ca}^{2+}$ activated $\mathrm{Mg}^{2+}$ dependent ATPase activity. The calcium pump is activated by a calcium binding protein called calmodulin. ${ }^{58}$

\section{Transmembrane water transport through water channels}

Aquaporin proteins are made up of six transmembrane a-helices arranged in a righthanded bundle with the amino and the carboxyl terminal located on the cytoplasmic surface of the membrane. ${ }^{68-73}$ The architecture of the aquaporin channel allows water molecules to pass only in single file while electrostatic tuning of the channel interior controls aquaporin selectivity against any charged species ${ }^{74.81}$ implying that only water molecules pass through the aquaporin water pore and transport of any ion as well as protons and hydroxyl ions is abolished. ${ }^{82-86}$

\section{Estimation and variation of erythrocyte volume}

The erythrocyte volume is assessed by the estimation of mean corpuscular volume (MCV) which is calculated with packed cell volume and erythrocyte count. ${ }^{87}$ The MCV can also be estimated by the use of volume-sensitive automated blood cell counters like the electronic Coulter counter. ${ }^{88}$

During erythrocyte maturation, the size of the cell decreases and ratio of cytoplasm to nucleus increases with the size of the nucleus diminishing until it completely disappears at maturation. ${ }^{89}$
Variation in erythrocyte volume could be observed when the cell is reduced (dehydrated) or increased (over hydrated) in size probably due to anisosmotic or isosmotic changes. ${ }^{6}$ The variations could also be caused by membrane ion channel disorders ${ }^{90,91}$ leading to an abnormally increased efflux or influx of cations and water.

\section{Regulatory volume adjustments in erythrocytes}

Regulatory volume decrease (RVD): A regulatory volume decrease (RVD) of cells is brought about by a net loss of cell solute together with osmotically obliged water. The RVD is achieved by increasing membrane permeability to solutes with an outwardly directed electrochemical gradient such as $\mathrm{K}^{+}$. The RVD occurs with the progressive net loss of cellular $\mathrm{K}^{+}, \mathrm{Cl}^{-}$and amino acids until the reduced cell volume has been attained and net fluxes cease. ${ }^{92}$

In many cells, swelling leads to the activation of non-selective cation channels. ${ }^{93}$ These channels do not directly serve cell volume regulation but allow the passage of $\mathrm{Ca}^{2+}$, which then enters the cells and activates $\mathrm{Ca}^{2+}$ sensitive $\mathrm{K}^{+}$channels. ${ }^{93}$

Stimulation of $\mathrm{Na}^{+}-\mathrm{Ca}^{2+}$ exchanger due to parallel extrusion of $\mathrm{Ca}^{2+}$ by the $\mathrm{Ca}^{2+}$-ATPase was reported in swollen erythrocytes. ${ }^{28}$

\section{Regulatory volume increase (RVI):}

Cell shrinkage inhibits $\mathrm{K}^{+}$and $\mathrm{Cl}^{-}$channels, preventing cellular electrolyte loss. ${ }^{93}$ The major ion transport systems accomplishing electrolyte accumulation in shrunken cells are the $\mathrm{Na}^{+}-\mathrm{K}^{+}-2 \mathrm{Cl}^{-}$cotransporter ${ }^{95}$ and the $\mathrm{Na}^{+} / \mathrm{H}^{+}$exchanger. The latter alkalinizes the cell leading to parallel activation of the $\mathrm{Cl}^{-}$$\mathrm{HCO}_{3}$ exchanger. The $\mathrm{H}^{+}$and $\mathrm{HCO}_{3}$ exchanged for $\mathrm{NaCl}$ by the $\mathrm{Na}^{+}-\mathrm{H}^{+}$exchanger and the $\mathrm{Cl}^{-}-\mathrm{HCO}_{3}{ }^{-}$exchanger are replenished within the cell from $\mathrm{CO}_{2} \cdot \mathrm{Na}^{+}-\mathrm{K}^{+}$-ATPase is also activated in RVI to replace accumulated $\mathrm{Na}^{+}$with $\mathrm{K}^{+} .94$ 
Some cells have been reported not to undergo RVI when exposed to hypertonic extracellular fluid. But the same cells will show RVD if exposed to hypotonic extracellular fluid; and if re-exposed to isotonic fluid, they will first shrink and then display RVI (secondary RVI or RVI on RVD). The inability of these cells to undergo primary RVI could be due to increased intracellular $\mathrm{Cl}^{-}$ activity. ${ }^{94}$

\section{Implications in pathophysiology}

Under normal circumstances, erythrocyte volume is always homeostatic but certain disorders (inherited or acquired) can alter the volume by either increasing (overhydrating) or decreasing (dehydrating) it resulting in haemolysis or eryptosis, respectively. This may be due to disorder during erythropoiesis, ${ }^{96}$ increased concentration of intracellular calcium, ${ }^{97}$ absence of membrane proteins ${ }^{98}$ and mutations of membrane proteins $^{99,}{ }^{100}$ or alterations in the activities of channels ${ }^{92,23}$ that are necessary for RVD and RVI. Overhydrated hereditary stomacytoses are caused by inherited autosomal genes that trigger an abnormal increase in $\mathrm{Na}^{+}$influx making the erythrocyte to be overhydrated. Dehydrated hereditary stomacytoses cause an excessive efflux of $\mathrm{K}^{+}$. Sickle cell disease, thalassemia, and hereditary spherocytosis are genetic disorders that cause erythrocytes to be dehydrated. ${ }^{8,98}$ Some heavy metals like lead have been reported to alter erythrocyte volume. ${ }^{101}$ Aquaporins have been reported to be involved in the pathophysiology of inflammatory diseases ${ }^{102-}$ ${ }^{105}$ by influencing movement of water alone or with either cerebrospinal fluid or glycerol across membranes ${ }^{105,106}$ in the gastrointestinal tract $^{107}$, salivary glands ${ }^{108}$, skin ${ }^{109}$, renal system $106,110,111$ and brain ${ }^{112}$ and altering erythrocyte volumes.

\section{Conclusions}

Erythrocyte volume is maintained at steady state not only by effective fluxes of ions via ion channels and carriers, but also by the presence of adequate aquaporins that facilitate obliged water movement across the membrane. A good knowledge of the types and functions of transport pathways available for ions and water across membranes can influence how researchers will design experiments.

\section{Conflict of Interest}

The author declares that there is no conflict of interest.

\section{Authors' Contribution}

The author was the only one involved in the literature search, collation and integration of the information, and writing of the literature review.

\section{REFERENCES}

1. Hattangadi SM, Wong P, Zhang L, Flygare J, Lodish HF. From stem cell to red cell: regulation of erythropoiesis at multiple levels by multiple proteins, RNAs, and chromatin modifications. Blood 2011;118(24):6258-6268.

2. Baron MH, Isern J, Fraser ST. The embryonic origins of erythropoiesis in mammals. Blood 2012;119(21):4828-4837.

3. Tvedten, H. Laboratory and clinical diagnosis of anemia. In: Weiss, D.J. and Wardrop. K.J.(Eds). Schalm's Veterinary Hematology. 6th edn, Wiley-Blackwell, USA 2010. p152-161.

4. Macknight ADC, Leaf A. Regulation of cellular volume. Physiol Rev 1977; 57:510-573.

5. Reece WO. (2015). Body water: properties

and functions. In: Reece WO, Erickson $\mathrm{HH}$, Goff JP, Uemura EE. (Eds). Dukes' Physiology of Domestic Animals. 13th edn. John Wiley and sons, USA. 2015. p 103-113.

6. Strange K. Cellular volume homeostasis. Adv Physiol Educ 2004; 28(14):155-159.

7. Pribush A, Meyerstein D, Meyerstein N. Kinetics of erythrocyte swelling and membrane hole formation in hypotonic media. Biochim Biophys Acta (BBA) Biomemb2002; 1558(2):119-132.

8. Rinehart I, Gulcicek EE, Joiner $\mathrm{CH}_{\text {, }}$ Lifton RP, Gallagher PG. Determinants of erythrocyte hydration. Curr Opin Heamatol 2010;17(3):191-197. 
9. Lang F, Birka C, Myssina S, Lang KS, Lang PA, Tanneur V, Duranton C, Wieder T, Huber SM. Erythrocyte ion channels in regulation of apoptosis. Adv Exp Med Biol 2004; 559:211-217.

10. Glogowska E, Gallagher PG. Disorders of erythrocyte volume homeostasis. Int Jnl Lab Hem 2015;37 (Suppl. 1):85-91.

11. Erwig LP, Henson PM. Clearance of apoptotic cells by phagocytes. Cell Death Differ 2008; 15:243-250.

12. Djuna Z D, Kostova EB, van Kraaij M, van den Berg TK, van Bruggen R. Of macrophages and red blood cells; a complex love story. Front Physiol 2014;5(9):1-11.

13. Poon IKH, Lucas CD, Rossi AG, Ravichandran KS. Apoptotic cell clearance: basic biology and therapeutic potential. Nat Rev Immunol 2014; 14:166-180.

14. Lang F, Busch GL, Ritter M, V lkl H, Waldegger S, Gulbins E, Häussinger D. Functional significance of cell volume regulatory mechanisms. Physiol Rev 1998; 78(1):247-306.

15. Blaustein MP, Kao JPY, Matteson DR. Ion channels In: Cellular physiology and neurophysiology. 2nd edn. Elsevier Mosby, Philadelphia, USA. 2012. p47-49.

16. Ballas SK, Krasnow SH. Structure of erythrocy te membrane and its transport functions. Annals of Clinical and Laboratory Science 1980; 10(3):209-219.

17. Blaustein MP, Kao JPY, Matteson D.R. Diffusion and permeability. In: Cellular physiology and neurophysiology. 2nd edn. Elsevier Mosby, Philadelphia, USA. 2012. p 7-14.

18. Baumgarten CM, Feher JI. Osmosis and regulation of cell volume. In: Cell Physiology Sourcebook: A molecular approach 3rd Edition. Ed Sperelakis S. Academic Press San Diego, California, USA. 2001. p319-356.

19. Hoffmann K, Dunham PB. Membrane mechanisms and intracellular signalling in cell volume regulation. Int Rev Cytol 1995; 161:173262.

20. O'Neil WC Physiological significance of volume-regulatory transporters. Am J Physiol Cell Physiol 1999; 276(5):C995-C1011.

21. Gardner K, Bennett GV. Recently identified erythrocyte membrane-skeletal proteins and interactions: Implications for structure and function. In: Agre, B. and Parker, J.C. (Eds). Red blood cell membranes; structure, function, clinical implications. Marcel Dekker, Inc, New York. 1989. p1-20.

22. Kirk K, Ellory JC, Young JD. Transport of organic substrate via a volume-activated channel. J Biol Chem 1992; 267:23475-23478.

23. Motais R, Fievet B, Borgese F, GraciaRomeu F. Association of the band 3 protein with a volume-activated anion and amino acid channel, a molecular approach. J Exp Biol 1997; 200 (Pt 2):361-367.

24. Coste B, Mathur J, Schmidt M, Earley TJ, Ranade S, Petrus MJ. Piezo1 and Piezo2 are essential components of distinct mechanically activated cation channels. Science 2010;330(6000):55-60.

25. Faucherre A, Kissa K, Nargeot J, Mangoni ME, Jopling C. Piezo1 plays a role in erythrocyte volume homeostasis. Haematologica 2014; 99:70-75.

26. Cahalan SM, Lukacs V, Ranade SS, Chien S, Bandell M,Patapoutian A. Elife 2015; 07370.012 DOI:http/ / dx.doi.org/10.7554.

27. Gardos G. The function of calcium in the potassium permeability of human erythrocytes. Biochim Biophys Acta 1958; 30:653-654.

28. Parker JC. Sodium and calcium movements in dog red blood cells. J Gen Physiol 1978; 71:1-17.

29. Grinstein S, Dupre A, Rothstein A. Volume regulation by human lymphocytes. Role of calcium. J Gen Physiol 1983; 79:849868.

30. Maher AD, Kuchel PW. The Gárdos channel: a review of the $\mathrm{Ca} 2+$-activated $\mathrm{K}+$ channel in human erythrocytes. Int J Biochem Cell Biol 2003;35(8):1182-1197.

31. Bogdanova A, Makhro A, Wang J, Lipp P, and Kaestner L.Calcium in red blood cells A peilous balance. Int J Mol Sci 2013; 14:9848-9872.

32. Mindukshev IV, Krivoshlky VV, Ermolaeva EE, Dobrylko IA, Senchenkov EV, Goncharov NV, Jenkins RO, Krivchenko Ai. Necrotic and apoptotic volume changes of red blood cells investigated by low-angle light scattering technique. Spectrosc 2007; 21:105- 
120.

33. Motais R, Guizouarn H,Borgese F. The swelling-sensitive osmolyte channel. In: Bernhart, I. and Ellory, J.C. (eds). Red cell membrane Transport in Health and Disease. Springer Berlin Heideberg, Germany. 2003; p 153-171.

34. Ellory JC, Dunham PB, Logue PJ, Stewart GW. Anion dependent cation transport in erythrocytes. Phil Trans Roy Soc Lond B 1982; 299:483-495.

35. Law RO, Burg MB. The role of organic osmolytes in the regulation of mammalian cell volume. In: Gilles $R$ (ed). Advances in Comparative and Environmental Physiology. Heidelberg Springer-Verlag 1991; p189-225.

36. Strange K, Emma F, Jackson PS. Cellular and molecular physiology of volume-sensitive anion channels. Am J Physiol 1996; 270:C711-C730.

37. Cossins AR, Gibson JS. Volume-sensitive transport systems and volume homeostasis in vertebrate red blood cells. J Exp Biol 1997; 200 (Pt 2):343-352.

38. Gibson JS, Hall AC. Stimulation of the $\mathrm{KCl}$ co-transport in equine erythrocytes by hydrostatic pressure: effects of kinase/phosphatase inhibition. Pflu" gers Arch1995;429: 446-448.

39. Bize I, Dunham PB. Staurosporine, a protein kinase inhibitor, activate $\mathrm{K}-\mathrm{Cl}$ cotransport in LK sheep erythrocytes. Am J Physol 1994; 266(Cell Physiol. 35): C759-C770.

40. Flatman PW, Adragna NC, Lauf PK. Role of protein kinases in regulating sheep erythrocyte KCl cotransport. Am J Physiol 1996; 271:C255C263.

41. Lauf PK, Adragna NC. K-Cl cotransport: properties and molecular mechanism. Cell Physiol Biochem 2000; 10:341-354.

42. Orlov SN, Kuznetsov SR, Kolosova IA, Aksentsev SL, Konev SV. Volume-dependent regulation of ion carriers in human and rat erythrocytes: role of cytoskeleton and protein phosphorylation. Ross Fizol Zh Im I M Sechenova 1997; 83(5-6):119-147.

43. Flatman PW. Regulation of Na-K-2Cl cotransport by phosphorylation and proteinprotein interactions. Biochim Biophys 2002; 1566 (1-2):140-151.

44. Kaji DM, Tsukitani Y. Role of protein phosphatase in activation of $\mathrm{KCl}$ cotransport in human erythrocytes. Am J Physiol 1991; 260(1 Pt1):C176-C180.

45. Campbell EH, Gibson JS. Oxygendependent $\mathrm{K}+$ fluxes in sheep red cells. J Physiol 1998; 506(Pt3):679-688.

46. Willis JS, Anderson GL. Activation of $\mathrm{K}-\mathrm{Cl}$ cotransport by mild warming in guinea pig red cells. J Membr Biol 1998; 163:193-203.

47. Lauf PK, Adragna NC. Temperatureinduced functional deocclusion of thiols inhibitory for sheep erythrocyte $\mathrm{K}-\mathrm{Cl}$ cotransport. Am J Physiol Cell Physiol 1995; 269:C1167-C1175.

48. Ellory JC, Hall AC, Ody SA. Factors affecting the activation and inactivation of $\mathrm{KCl}$ cotransport in 'young' human red cells. Biomedica Biochimica Acta 1990; 49(2-3):564569.

49. Ellory, J.C. and Tucker, E.M. Cation transport in red cells. In: Agar NS, Board PG. (eds) Red blood cells of domestic animals. Amsterdam. Elsevier. 1983; p291-314.

50. Olver CS, Andrew GA, Smith JE, Kaneko JJ. (2010). Erythrocyte structure and function. In: (Weiss DJ, WardropKJ (eds). Schalm's Veterinary Hematology. 6th edn Wiley-Blackwell, Iowa. 2010; p123-130.

51. Lauf PK, Bauer J, Adragna NC, Fujise $\mathrm{H}$, Zada-oppen AM, Ryu KH, Delpire E. Erythrocyte K-Cl cotransport: properties and regulation. Am J Physiol Cell Physiol 1992; 263:C917-C932.

52. Russell JM. Sodium-potassiumchloride cotransport. Physiol Rev 2000; 80:211-276.

53. Rapetti-Mauss R, Picard V, Guitton C, Ghazal K, Proulle V, Badens C, Soriani O, Garcon L, Guizouarn H. Red blood cell Gardos channel (KCNN4): the essential determinant of erythrocyte dehydration in hereditary xerocytosis. Haematologica 2017; 102(10):e415-e418.

54. Sen AK, Post RL. Stoichiometry and localisation of adenosine triphosphatedependent sodium and potassium transport in the erythrocyte. J Biol Chem 1962; 239:345352.

55. Garrahan PJ, Glynn IM. The 
stoichiometry of the sodium pump. J Physiol 1967;192: 217-235.

56. Post RL, Albright CD, Dayani K. Resolution of pump and leak components of sodium and potassium ion transport in human erythrocytes. J Gen Physiol 1967; 50:1201-1220.

57. Shalev O, Mogilner S, Shinar E, Rachmilewitz EA, Schrier SL. Impaired erythrocyte calcium homeostasis in betathalassemia. Blood 1984; 64(2):564-566.

58. Harvey JW. The erythrocyte: physiology, metabolism and biochemical disorders. In: Kaneko JJ, Harvey JW, Bruss ML (eds). Clinical Biochemistry of Domestic Animals. 6thedn. Elsevier. San Diego. 2008; p173-240.

59. Roudier N, Verbavatz JM, Maurel C, Ripoche P, Tacnet F. Evidence for the presence of aquaporin-3 in human red blood cells. J Biol Chem $1998 ; 273: 8407-8412$.

60. Heymann JB, Engel A. Aquaporins: phylogeny, structure and physiology of water channels. News Physiol Sci 1999;14:187-193.

61. Vidossich P, Cascella M, Carloni P. Dynamics and energetics of water permeation through the aquaporin channel. Proteins 2004; 55:924-931.

62. Kuchel PW Benga G. Why does the mammalian red blood cell have aquaporins? Biosystems 2005; 82(2):189-96.

63. Endeward V, Musa-Aziz R, Cooper GJ, Chen LM, Pelletier MF, Virkki LV, Supuran CT, King LS, Boron WF, Gros G. Evidence that aquaporin 1 is a major pathway for $\mathrm{CO} 2$ transport across the human erythrocyte membrane. FASEB J 2006; 20(12):1974-1981.

64. Agre P, Bonhivers M, Borgnia MJ. The aquaporins, blueprints for cellular plumbing systems. J Biol Chem 1998; 273:14659-14662.

65. Murata K, Mitsuoka T, Hirai T, Walz T, Agre P, Heymann AE, Fujiyoshi Y. Structural determinants of water permeation through aquaporin-1. Nature 2000; 407:599-605.

66. Yakata K, Hiroaki Y, Ishibashi K, Sohara E, Sasaki S, Mitsuoaka K, Fujiyoshi Y. Aquaporin-11 containing a divergent NPA motif has a normal water channel activity. Biochim Biophys Acta (BBA) - Biomemb 2007;1768(3):688-693.

67. Takata K, Matsuzaki T,Tajika Y. Aquaporins: water channel proteins of the cell membrane. Prog Histochem Cytochem2004; 39(1):1-83.

68. Borgnia M, Nielsen S, Engel A, Agre P. Cellular and molecular biology of the aquaporin water channels. Annu Rev Biochem 1999; 68:425-458.

69. Mitsuoka K, Murata K, Walz T, Hirai T, Agre P, Heymann JP, Engel A, Fujiyoshi Y. The structure of aquaporin-1 at 4.5-A resolution reveals short alpha-helices in the center of the monomer. J Struc Biol 1999; 128(1):34-43.

70. Stahlberg H, Heymann B, Mitsuoka K, Fuyijoshi Y, Engel A. The aquaporin superfamily: structure and function; $\mathrm{AQP}$, the erythrocyte water channel. In: Hohmann S, Agre P (eds). Aquaporin. Academic Printers, California, USA. 2001; p 47-74.

71. Wspalz T, Fujiyoshi Y, Engel A. The AQP structure and functional implications. In: Beitz E (ed).Aquaporin. Springer, Heidelberg, Germany. 2004; p31-56.

72. Zhu F, Tajkhorshid E. Theory and simulation of water permeation in aquaporin1. Biophys J 2004; 86(1):50-57.

73. Gonen T, Walz T. The structure of aquaporins. Q Rev Biophys 2006; 39(4):361396.

74. de Groot BL, Grubmüller H. Water permeation across biological membranes: mechanism and dynamics of aquaporin- 1 and GlpF. Science 2001; 294:2353-2357.

75. Burykin A, Warshel A. What really prevents proton transport through aquaporin? Charge self-energy versus proton wire proposals. Biophys J 2003; 85(6):36963706.

76. de Groot BL, Frigato T, Helms V, Grubmüller $\mathrm{H}$. The mechanism of proton exclusion in the aquaporin-1 water channel. J Biol 2003; 333:279-293.

77. Jensen MO, Tajkhorshid E, Schulten K. Electrostatic tuning of permeation and selectivity in aquaporin water channels. Biophys J 2003; 85:2884-2899.

78. Zhu F, Tajkhorshid E, Schulten K. Molecular dynamics study of aquaporin-1 water channel in a lipid bilayer. FEBS Lett. 2001; 504:212-218. 
79. Chakrabarti N, Tajkhorshid E, Roux B, Pomes R. Molecular basis of proton blockage in aquaporins. Structure 2004, 12:65-67.

80. Ilan B, Tajkhorshid E, Schulten K, Voth GA. The mechanism of proton exclusion in aquaporin channels. Proteins 2004; 55:223-228.

81. Yu J, Yool AJ, Schulten K, Tajkhorshid E. Mechanism of gating and ion conductivity of a possible tetrameric pore in aquaporin-1. Structure 2006; 14(9):1411-1423.

82. Sui H, Han BG, Lee JK, Walian P, Jap BK. Structural basis of water-specific transport through the AQP1 water channel. Nature 2001; 414:872-878.

83. Day R E, Kitchen P, Owen DS, Bland C, Marshal L, Conner AC, Bill RM and Conner MT (2014). Human aquaporins: Regulators of transcellular water flow. Biochim Biophys Acta (BBA)-General subjects 2014;1840(5):1492-1506.

84. Agre P. Nobel lecture. Aquaporin water channels. BioSci Rep 2004; 24:127-163.

85. Benga G. Water channel proteins (later called aquaporins) and relatives: past, present and future. Life 2009; 61(2):112-133.

86. Brown D. The discovery of water channels (aquaporins). Ann Nutr Metab 2017; 70(Suppl): $37-42$.

87. Sarma PR. In: Walker HK, Hall WD, Hurst JW (eds). Clinical methods: The history, physical and laboratory examination. 3rd edition. Boston; Butterworths. 1990; p102-130.

88. Moritz, A. and Becker, M. Automated heamatology systems. In: Weiss DJ, Wardrop KJ (eds). Schalms Veterinary Hematology. 6th edn. Wiley-Blackwell, USA. 2010; p 1054-1066.

89. Sharkey LC, Hill SA. Structure of bone marrow. In: Weiss DJ, Wardrop KJ (eds). Schalm's Veterinary Hematology. 6th edn. WileyBlackwell, USA. 2010; p 8-13.

90. Stewart GW. Haemolytic disease due to membrane ion channel disorders. Curr Opin Hematol 2004; 11(4):244-250.

91. King MJ, Zanella A. Hereditary red cell membrane disorders and laboratory diagnostic testing. Int J Lab Hematol 2013; 35(3):237-243.

92. Garcia-Romeu F, Cossins AR, Motais R. Cell volume regulation by trout erythrocytes: characteristics of the transport systems activated by hypotonic swelling. J Physiol 1991; 440:547-567.
93. Lang F, Busch GL, V lkl H.). The diversity of volume regulatory mechanisms. Cell Physiol Biochem 1998; 8:1-45.

94. Christensen O. Mediation of cell volume regulation by $\mathrm{Ca} 2+$ influx through stretch-activated channels. Nature 1987; 330: 66-68.

95. Geck P, Pfeiffer B. Na+ $\mathrm{K}+2 \mathrm{Cl}-$ cotransport in animal cells: its role in volume regulation. Ann NY Acad Sci 1985; 456: 166182.

96. Delaunay J, Cartron J. Disorders of the red cell membrane. In: Disorders of erythropoiesis, erythrocytes and iron metabolism. The handbook, 2009 edition. USA. 2009; p 402-435.

97. Engelmann B. Calcium homeostasis of human erythrocytes and its pathophysiological implication. Klinische Wochenschrift 1991; 69(4):137-142.

98. Gallagher PG. Disorders of red cell volume regulation. Curr Opin Hematol 2013; 20(3):210-217.

99. Kay MM. Band 3 and its alterations in health and disease. Cell Mol Biol (Noisy-legrand) 2004;50(2):117-138.

100. Iolascon A, De Falco L, Borgese $\mathrm{F}$, Esposito MR, Avvisati RA, Izzo P, Piscopo C, Guizouarn H, Biondani A, Pantaleo A, De Franceschi L. A novel erythroid anion exchange variant (Gly796Arg) of hereditary stomatocytosis associated with dyserythropoiesis. Hematol 2009; 94(8):10491059.

101. Jaishankar M, Tseten T. Toxicity, mechanism and health effects of some heavy metals. Interdiscip Toxicol 2014; 7(2):60-72.

102. Sisto M, Ribatti D, Lisi S. Aquaporin water channels: New perspective on the potential role in inflammation. Adv Protein Chem Struct Biol 2019;116:311-345.

103. Meli R, Pirozzi C, Pelagalli A. New perspectives on the potential role of aquaporins (AQPs) in the physiology of inflammation. Front Physiol 2018; https//doi.org/10.3389/fphys.2018.00101.

104. Mariajoseph-Anthony LF, Kannan A, Panneerselvam A, Loganathan C, Shankar Em, Anbarasu K, Prahalathan C. Role of 
aquaporins in inflammation- a scientific curation. Inflammation 2020; doi: 10.1007/s10753-02001247-4.

105. Li C, Wang W. Molecular biology of aquaporins. Adv Exp Med Biol 2017; 969:1-34.

106. Zhu C, Chen Z, Jiang Z. Expression, distribution and role of aquaporin water channels in human and animal stomach and intestines. Int J Mol Sci. 2016;17(9):1399-1417.

107. Delporte C, Bryla A, Perret J. aquaporins in salivary glands: From basic research to clinical applications. Int J MolSci. 2016; 17(2):166-179.

108. Bollag WB, Aitkens L, White J, Hyndman
KA. Aquaporin-3 in the epidermis: more than skin deep. Am J Physiol 2020; 318(6): C1144C1153.

109. King LS, Choi M, Fernandez Pc, Cartron J, Agre P. Defective urinary concentrating ability due to a complete deficiency of aquaporin-1. N Engl J Med 2001; 345:175-179.

110. Yang B, Ma T, Verkman AS. Erythrocyte water permeability and renal function in double knockout mice lacking aquaporins-1 and aquaporin-3. J Biol Chem 2001;276(1):624-628.

Cite this article as: Igbokwe NA. Transmembrane Ion And Water Transports In Erythrocyte Volume Homeostasis: An Overview Of The Physiologic Processes.

KJMS 2020; 14(2): 95 - 105. 